\section{Nitrogen deposition regulates the clonal growth of Leymus chinensis, a typical clonal plant in arid and semi-arid regions}

Clonal growth of Leymus chinensis

Li Liu, ChengYang Zhou, Xiao Pei, LiZhu Guo and JiaHuan Li College of Grassland Science and Technology, China Agricultural University, Beiing, China

RuiXin Wu

Hebei Academy of Agricultural and Forestry Sciences, Dryland Farming Institute, Shijiazhuang, China, and

Ding Huang

College of Grassland Science and Technology, China Agricultural University, Beijing, China

\begin{abstract}
Purpose - The purpose of this study is to examine the effects of nitrogen $(\mathrm{N})$ deposition on clonal growth in a rhizome clonal plant, Leymus chinensis (Trin.) Tzvel.

Design/methodology/approach - The study established seven $N$ concentration gradients $(0,2,4,8,16$, 32 and $64 \mathrm{~g} \mathrm{~N} \mathrm{~m}^{-2}$ ) to simulate the continuous increase in $\mathrm{N}$ deposition for the cultivation of $\mathrm{L}$. chinensis seedlings and assess the response mechanism of the cloned L. chinensis plant at different $\mathrm{N}$ levels by analyzing the aboveground and belowground plant appearance traits, parent ramets and daughter ramets of resource allocation and biomass allocation.

Findings - The results of this study showed that the different $\mathrm{N}$ treatment levels could promote clonal growth and had certain regularity under the seven treatments. The addition of $\mathrm{N}$ could significantly increase the ramet number, rhizome length, rhizome spacer length, biomass of mother ramets, daughter ramets and belowground L. chinensis population when the $\mathrm{N}$ addition was greater than $4 \mathrm{~g} \mathrm{~m}^{-2}$; however, the clonal growth ability of $\mathrm{L}$. chinensis decreased and the rhizome length, ramet number, stem and leaf biomass of daughter ramets and stem biomass of mother ramets significantly decreased when the $\mathrm{N}$ addition was greater than $32 \mathrm{~g} \mathrm{~N} \mathrm{~m}^{-2}$.
\end{abstract}

(c) Li Liu, ChengYang Zhou, Xiao Pei, LiZhu Guo, JiaHuan Li, RuiXin Wu, and Ding Huang. Published by Emerald Publishing Limited. This article is published under the Creative Commons Attribution (CC BY 4.0) licence. Anyone may reproduce, distribute, translate and create derivative works of this article (for both commercial \& non-commercial purposes), subject to full attribution to the original publication and authors. The full terms of this licence may be seen at http://creativecommons.org/ licences/by/4.0/legalcode

Acknowledgements: We acknowledge and thank all authors of this studies.

Funding: This study was funded by the National Key Research and Development Plan Program (2018YFD0502402-5, 2016YFC05051902), and the Beijing Scientific Committee project of China (Z181100009618031).

Conflicts of interest: The authors do not have any conflicts of interest to report.

This paper forms part of special section "Climate change impacts and adaptations in arid and semi-arid regions", guest edited by Zhihua Zhang, Qiang Zhang and Muhammad Jawed Iqbal.
Received 24 June 2020 Revised 16 August 2020 Accepted 17 August 2020 
IJCCSM 12,5

Originality/value - With global warming, atmospheric N deposition is increasing and it is of great significance to explore the response mechanism of different $\mathrm{N}$ levels for the growth of clone plants. This study provides basic data and a theoretical basis for the survival prediction of cloned plants under the background of a global climate change strategy and has important theoretical and practical significance for the scientific management of grasslands in the future.

Keywords Biomass allocation, Nitrogen deposition, Clonal growth, Leymus chinensis, Plant trait

Paper type Research paper

\section{Introduction}

With the development of society, human factors such as industrial production and agricultural activities cause drastic changes in the global climate, including climate warming, changes in precipitation patterns and atmospheric nitrogen $(\mathrm{N})$ deposition, which have an important impact on terrestrial ecosystems. Changes in these environmental factors are accompanied by changes in the biodiversity, productivity and phenological, physiological and reproductive characteristics of the plant communities in an ecosystem (Frenne et al., 2018; Bogdziewicz et al., 2017). Arid and semi-arid areas account for about $30 \%$ of the total land area of the world, which are one of the more sensitive areas for climate change due to their lack of water resources, fragile ecological environment. Under the influence of global climate change, the trend of drought is obviously strengthened, the water restriction is more prominent and the climate continues to warm, which have important influences on the ecosystem of arid and semi-arid regions. Moreover, with the aggravation of global climate change, $\mathrm{N}$ deposition has become a global ecological environment problem that attracts much attention at this stage.

Atmospheric $\mathrm{N}$ deposition is one of the major changes caused by global climate change (Vitousek et al., 1997; Vet et al., 2014; Liu et al., 2016). The anthropogenic emissions of reactive N and its accumulation in the soil have doubled since the 1890s and are expected to double again by 2050 (Galloway et al., 2004, 2008). At present, the increase in N input caused by human activities exceeds that provided by nature (Galloway et al., 2004) and the rapid input of $\mathrm{N}$ affects the organisms themselves and their interactions. Nitrogen is the most important environmental factor affecting plant productivity in arid and semi-arid regions except temperature and precipitation (Hooper and Johnson, 1999). Affected by various human activities and natural causes, active nitrogen compounds in the atmosphere surge. Nitrogen enters the soil in the form of the pulse along with precipitation (snow) and fog, causing changes in nitrogen and other nutrient elements and forming sufficient nutrient supply in a short period. The increase in $\mathrm{N}$ input has an important impact on biological activities such as plant biodiversity and ecosystem function (Bobbink et al., 2010; Simkin et al., 2016). For example, $\mathrm{N}$ input will increase the aboveground biomass of plants (Bobbink et al., 2010; Isbell et al., 2013), leading to changes in plant community composition and structure (Clark and Tilman, 2008; Farrer and Suding, 2016); N also changes the physical and chemical properties of the soil and promotes the underground growth of plants (Tian et al, 2015, 2016). Different plant species or organs have different uptake and utilization methods based on $\mathrm{N}$ availability, which changes the growth history of plants through competition (Hautier et al., 2009).

When the characteristics of plants under environmental conditions or conditions with limited resources can reflect their adaptive strategies (Garnier et al., 2017; Iversen et al., 2017; Walker et al., 2018), plants will match the acquisition of resources aboveground, belowground and between organs for optimal growth (Valverde-Barrantes et al., 2017). When $\mathrm{N}$ is adequate, it will promote photosynthesis in plants, but when it is excessive, it will lead to the deposition of $\mathrm{N}$ in plants and the increase in $\mathrm{N}$ concentration will change the $\mathrm{N}$ metabolic cycle in plants, resulting in an imbalance of the nutrient element content and 
reducing the photosynthetic rate of the plant (Bauer et al., 2004; Zheng et al., 2015). Too much $\mathrm{N}$ will cause an imbalance in $\mathrm{C}-\mathrm{N}$ metabolism in plants and inhibit plant growth (Barker et al., 2004; Michopoulos et al., 2004). N deposition will also affect the external morphological structure of plants to some extent and can reduce the root-shoot ratio of plants. Nonetheless, under different environmental conditions, the plant trade-offs between different organ strategies and machine quality are still not clear.

Grassland ecosystem is the main part of the ecosystem in arid and semi-arid regions. It is the sensitive and ecologically fragile zone of climate change and the ideal place to study the influence of climate change on the terrestrial system. Clone plants occupy a large proportion of the perennial grassland, which reproduce modes both sexually and asexually (Koivunen et al., 2004). Due to the long-term adaptation to the environment, a number of clonal plants have abandoned or used sexual reproduction less and energy is mainly allocated to asexual reproduction (Eckert, 2002; Philbrick and Les, 1996). Therefore, the capacity of clone plants to reproduce asexually on perennial grassland can be a good prediction of the productivity of the perennial grassland. Leymus chinensis is a typical clone plant and it will choose different reproductive strategies in different habitats and conditions; however, it mainly focuses on clone reproduction and belowground transverse rhizome growth is the main organ used for clone reproduction. With increasing $\mathrm{N}$ deposition, the nutrient is bound to have an important impact on the growth of the L. chinensis population and the grassland with $L$. chinensis is the dominant plant population.

Under the background condition of increasing $\mathrm{N}$ deposition, L. chinensis was grown under different $\mathrm{N}$ concentration gradients to assess the traits of differences and correlation relations to explore the response mechanism of that on $\mathrm{N}$ deposition, enabling a better understanding the ecological adaptation strategies of dominant species in grassland ecosystems in arid and semi-arid regions under the background of global climate change, this research has important scientific significance and can help predict the productivity of grassland ecosystem in arid and semi-arid regions under the background of global climate change. It also provides the basic data and a theoretical basis for future work, and this work has important theoretical and practical significance in the future scientific management of grassland. In this study, we set up seven $\mathrm{N}$ concentration gradients $(0,2,4,8,16,32$ and $64 \mathrm{~g}$ $\mathrm{N} \mathrm{m}^{-2}$ ) for the cultivation of $L$. chinensis seedlings and assessed the response mechanism of the cloned plant $L$. chinensis in the different $\mathrm{N}$ levels by analyzing the aboveground and belowground plant appearance traits, ramet and genet of resource allocation and biomass allocation. This experiment mainly tested the following questions: First, how do different $\mathrm{N}$ concentrations affect the clone growth of L. chinensis? Second, what are the strategies for biomass allocation between the shoots and roots across the $\mathrm{N}$ gradient treatment?

\section{Materials and methods}

\subsection{Experimental design}

The experiment was conducted from June to October 2019 in a greenhouse at China Agricultural University in Beijing, China. In the artificial L. chinensis grassland of Guyuan National Field Station of China Agricultural University, seedlings with consistent growth and light green color were selected and brought back to the greenhouse. The rhizome was cut off into a single ramet for plant propagation, and all ramets were of similar size and developmental stage. After the seedlings were treated, they were transplanted into a pot that was $25 \times 20 \mathrm{~cm}$, in which the ratio of perlite and vermiculite was 1:1 and the weight was approximately $\pm 0.85 \mathrm{~kg}$, with 10 plants per pot. After the seedlings were sown for one week, the pot was filled with 6 plants. After reaching a constant volume, the nutrient solution was supplemented. The nutrient solution was formulated with $\mathrm{N}$-deficient 
IJCCSM

12,5

Hoagland nutrient solution. The experiment was set up based on a randomized complete block design with $\mathrm{N}$ addition as the only factor. In total, 35 pots were randomly selected for the $\mathrm{N}$ addition treatment and seven $\mathrm{N}$ gradient treatments were performed, including $0,2,4$, $8,16,32$ and $64 \mathrm{~g} \mathrm{~N} \mathrm{~m}^{-2}$ (46\% urea). Five pots were randomly selected for each treatment as replicates. Urea (N, 46\%) was applied together with the nutrient supplement for a one-time application. After nutrient supplementation and $\mathrm{N}$ treatment, deionized water was poured on the plants every 7 days, $1 \mathrm{~L}$ each time. The location of each pot was randomly assigned. To minimize the impact of greenhouse environmental differences on growth, the pots in each area were rotated every two days.

\subsection{Parameter measurements}

L. chinensis was harvested after 90 days of growth. The aboveground part of the plant was distinguished from the daughter ramets and the mother ramets; the ramet height, the number of rhizome-based ramets and the number of tiller-based ramets were measured and counted; additionally, the stems and leaves of the daughter ramets and the parent ramets were separated (Bai et al., 2009; Batzer et al., 2017; Zheng and Ma, 2018). The belowground part was removed and washed with running water, and the rhizome length and spacer length were measured. As the belowground part of L. chinensis was mainly rhizome, the root and rhizome were not separated in this study. The differentiated stems, leaves, roots and rhizomes were oven-dried for $48 \mathrm{~h}$ at $80^{\circ} \mathrm{C}$ and then weighed.

\subsection{Data analyzes}

All statistical analyzes were conducted with IBM SPSS Statistics 22.0, and figures were plotted with Sigma Plot 12.5. Then, the "vegan" in program R. Data were analyzed by oneway ANOVA followed by Duncan's multiple range tests to determine the statistical significance of the effects of the $\mathrm{N}$ treatment. We set $p<0.05$ as the significance level, and the results are presented as the mean +SE. We calculated the following parameters: root/ shoot $(\mathrm{R} / \mathrm{S})$ = belowground biomass/aboveground biomass; root mass ratio $(\mathrm{RMR})=$ root dry mass/total plant dry mass; stem mass ratio (SMR) = stem dry mass/total plant dry mass; leaf mass ratio $(\mathrm{LMR})=$ leaf dry mass/total plant dry mass; stem/leaf ratio (SLR) = stem dry mass/leaf dry mass.

\section{Results}

\subsection{Effect of $N$ addition on ramet number of L. chinensis}

The number of tiller-based and rhizome-based ramets of L. chinensis was significantly affected by $\mathrm{N}$ addition. The number of these ramets increased significantly when the $\mathrm{N}$ concentration was greater than $4 \mathrm{~g} \mathrm{~N} \mathrm{~m}^{-2}$ and reached the maximum value at $32 \mathrm{~g} \mathrm{~N} \mathrm{~m}^{-2}$ $(p<0.05)$; moreover, the number of tiller-based ramets was higher than that of rhizomebased ramets across the $\mathrm{N}$ addition gradient (Figure 1).

\subsection{Effect of $N$ addition on the biomass allocation of L. chinensis}

The total biomass, aboveground biomass and belowground biomass of L. chinensis significantly increased across the $\mathrm{N}$ addition gradient; however, when the $\mathrm{N}$ treatment was greater than $32 \mathrm{~g} \mathrm{~N} \mathrm{~m}^{-2}$, the total biomass and belowground biomass decreased significantly $(p<0.05)$, while the aboveground biomass tended to be flat [Figure 2(a)]. The belowground biomass was more sensitive to $\mathrm{N}$ addition than the aboveground biomass when the $\mathrm{N}$ treatment was less than $16 \mathrm{~g} \mathrm{~N} \mathrm{~m}^{-2}$. The R/S showed high sensitivity to N addition, as indicated by the sharp increase at the low $\mathrm{N}$ addition rates (less than $4 \mathrm{~g} \mathrm{~N} \mathrm{~m}^{-2}$ ) [Figure 2(b)]. 


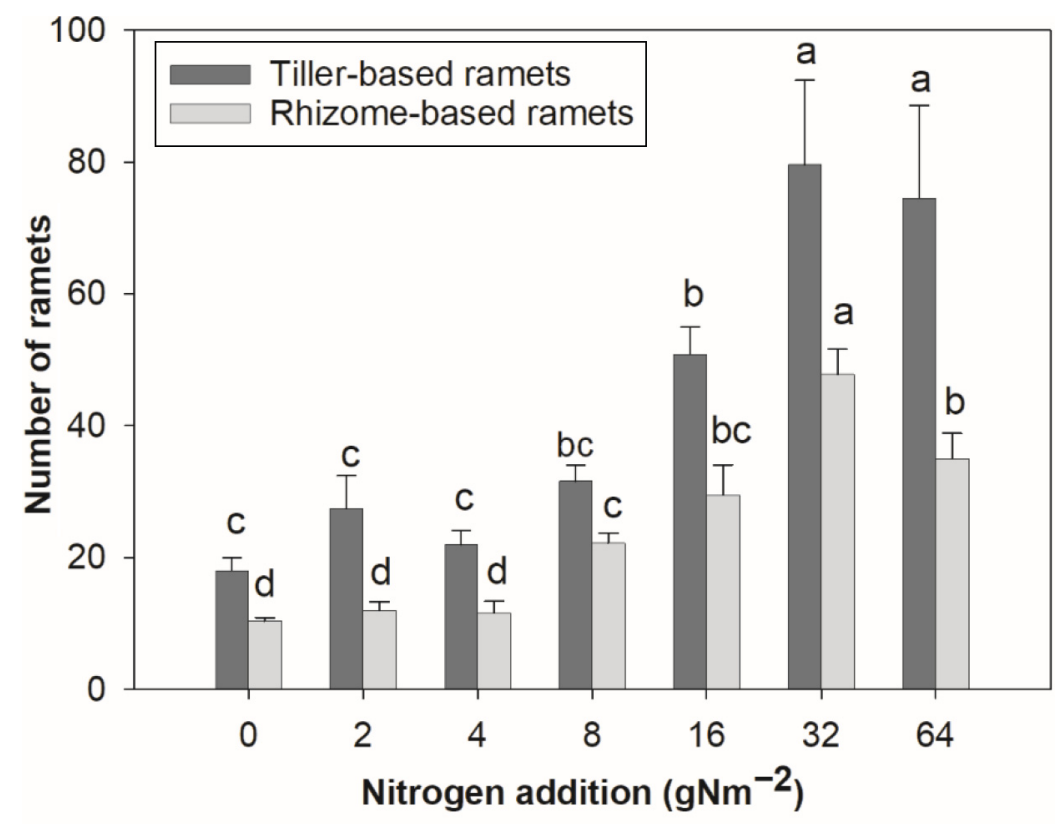

Notes: Results presented as means + SE. The different letters indicate significant differences determined by the Duncan test at the 0.05 significance level

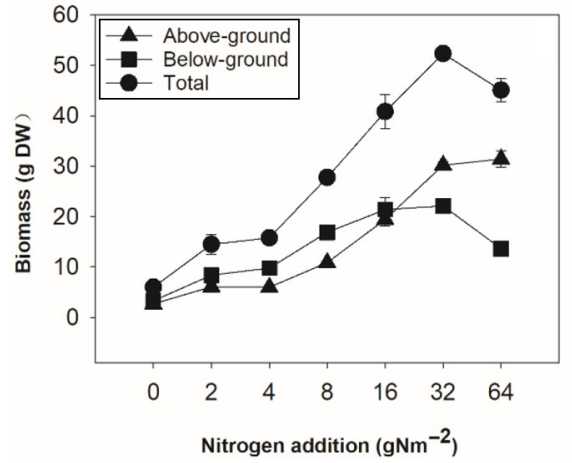

(a)

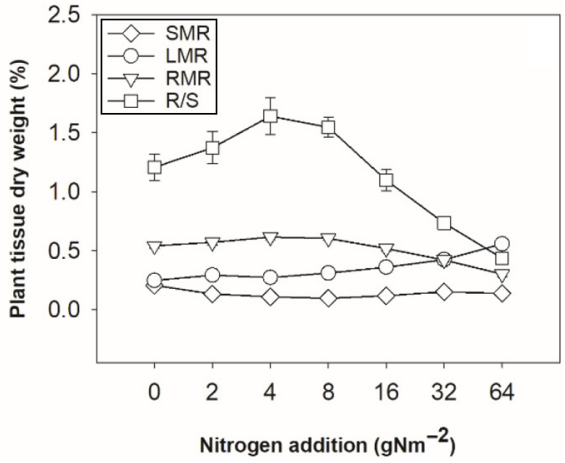

(b)

Notes: Abbreviations indicate the following: $\mathrm{SMR}=$ stem mass ratio; $\mathrm{LMR}=$ leaf mass ratio; $\mathrm{RMR}=$ root mass ratio; $\mathrm{R} / \mathrm{S}=$ root $/$ shoot

In the treatment with no $\mathrm{N}$ addition, the relative contribution of RMR was higher than that for leaves and stems, but it decreased with the addition of $\mathrm{N}$ (more than $4 \mathrm{~g} \mathrm{~N} \mathrm{~m}^{-2}$ ). In contrast, the relative contribution of LMR increased significantly across the $\mathrm{N}$ addition gradient and was higher than that of roots under the treatment receiving the higher rates of $\mathrm{N}$ addition (more 
IJCCSM

12,5

\section{2}

Figure 3.

The rhizome length and rhizome spacer length of Leymus chinensis across the $\mathrm{N}$ addition gradient than $32 \mathrm{~g} \mathrm{~N} \mathrm{~m}^{-2}$ ). Across the whole $\mathrm{N}$ addition gradient, the relative contribution of SMR was lower than that of leaves and roots [Figure 2(b)].

\subsection{Effect of $N$ addition on rhizome traits}

The rhizome length showed a significant difference under the $\mathrm{N}$ gradient treatment. With increasing $\mathrm{N}$ concentration, the rhizome length increased significantly, reached a maximum at $32 \mathrm{~g} \mathrm{~N} \mathrm{~m}^{-2}$ and then decreased significantly $(p<0.05)$ (Figure 3$)$. In addition, the rhizome spacer length was significantly higher after $\mathrm{N}$ addition than that with no $\mathrm{N}$ addition $(p<0.05)$ and reached the highest value at $32 \mathrm{~g} \mathrm{~N} \mathrm{~m}^{-2}$ (Figure 3).

\subsection{Effect of $N$ addition on daughter ramet mass and parent ramet characteristics}

The aboveground biomass increased with the $\mathrm{N}$ addition gradient, but the trends of the daughter and mother ramets and different tissues were different $(p<0.05)$. In terms of biomass allocation in different tissues, both the daughter ramets and the mother ramets were allocated more to the leaves. The biomass of daughter plants, stems and leaves increased with the $\mathrm{N}$ gradient but decreased when the $\mathrm{N}$ concentration was greater than $32 \mathrm{~g} \mathrm{~N} \mathrm{~m}^{-2}$ [Figure 4(a)]. The mother plant mass and leaf mass increased with the $\mathrm{N}$ addition gradient, while the stem biomass decreased when the $\mathrm{N}$ concentration was greater than $32 \mathrm{~g} \mathrm{~N} \mathrm{~m}^{-2}$ [Figure 4(b)]. The variation trend of the stem, leaf and biomass of the mother plant was consistent with that of the aboveground biomass [Figure 4(c)].

The plant height of $L$. chinensis increased with the $\mathrm{N}$ addition gradient. The height of the parent ramet was higher than that of the daughter ramet under each treatment $(p<0.05)$ [Figure 4(d)]. With the increase in $\mathrm{N}$ concentration, the stem/leaf ratio of the mother ramet and daughter ramet decreased significantly, but when the concentration was greater than $8 \mathrm{~g} \mathrm{~N} \mathrm{~m}^{-2}$, the mother ramet tended to increase; additionally, at values greater than $32 \mathrm{~g} \mathrm{~N} \mathrm{~m}^{-2}$, it decreased, while the daughter ramet remained stable [Figure 4(e)]. In addition, the daughter/parent ramet mass ratio decreased significantly when the $\mathrm{N}$ concentration was low (less than $8 \mathrm{~g} \mathrm{~N} \mathrm{~m}^{-2}$ ) [Figure 4(f)].

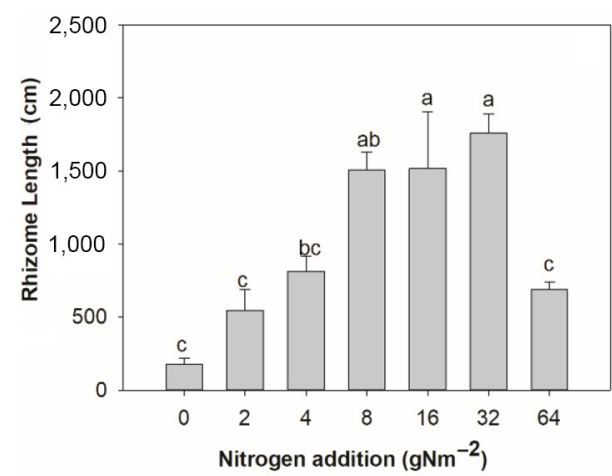

(a)

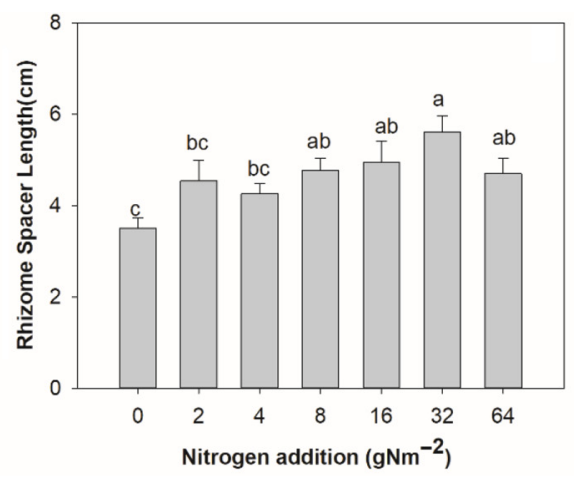

(b)
Notes: Results presented as means + SE. The different letters indicate significant differences determined by the Duncan test at the 0.05 significance level 


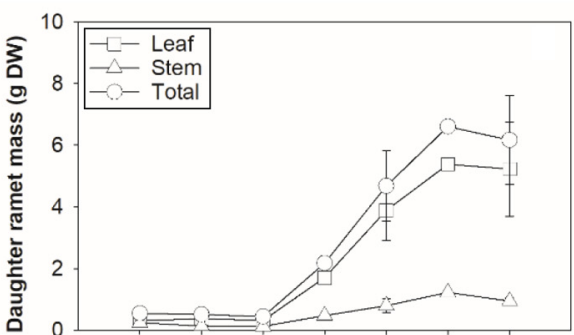

(a)

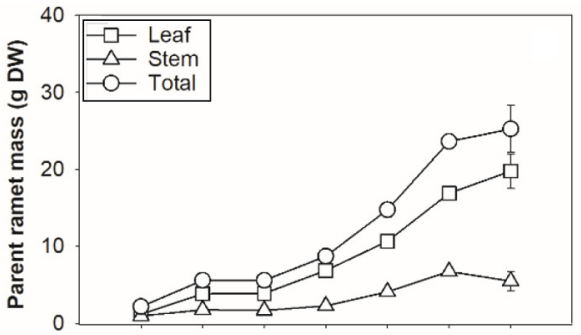

(c)

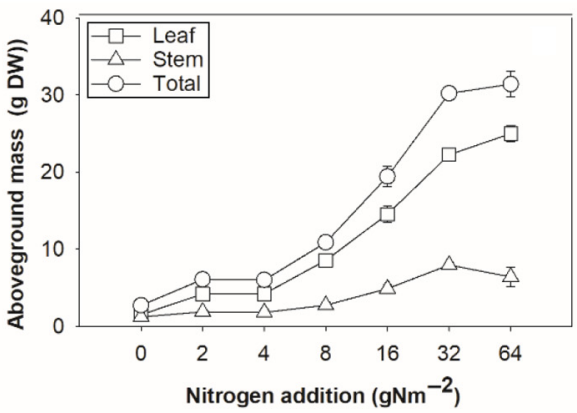

(e)

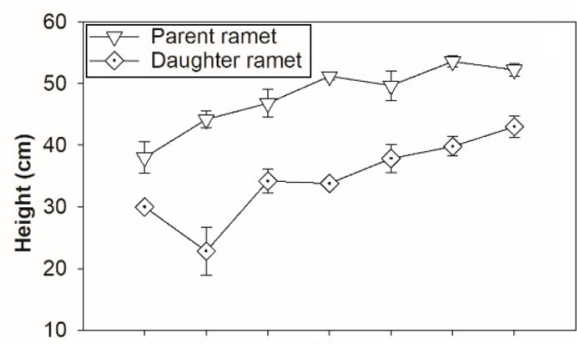

(b)

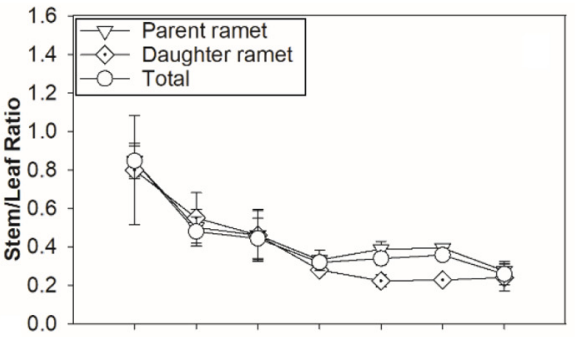

(d)

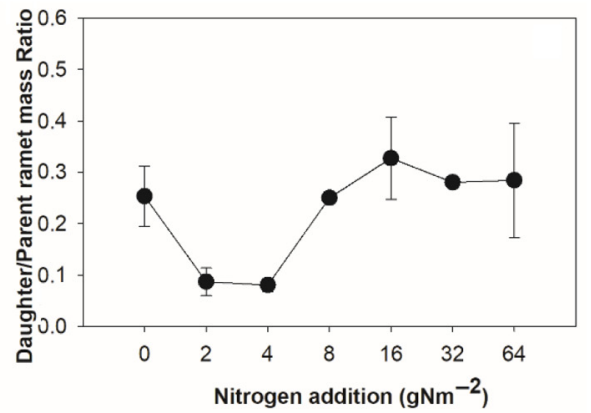

(f)
Clonal growth of Leymus chinensis

563

Figure 4.

The differences of daughter ramet mass ịaboveground biomass、 ịparent ramet mass、 ịheight 、ịstem/leaf ratio、ịdaughter/ parent ramet mass ratio of Leymus chinensis across the $\mathrm{N}$ addition gradient

\subsection{Correlation analysis among plant growth traits in each $N$ treatment}

The tiller number $(\mathrm{N}-\mathrm{T})$, ramet number $(\mathrm{N}-\mathrm{R})$, plant height, rhizome length (RL), rhizome space length (RSL) and biomass index of L. chinensis were significantly positively correlated with each other, while the stem/leaf ratio of daughter ramets (DSLR) was significantly negatively correlated with the indexes listed above $(P<0.05)$. The root mass ratio (RMR) and root/shoot ratio $(\mathrm{R} / \mathrm{S})$ were negatively correlated with the leaf mass ratio (LMR), total biomass, aboveground biomass (AS), plant height, N-T and N-R and positively correlated with the stem/leaf ratio (SLR). In contrast, the LMR was positively correlated with the biomass index and height, N-T and N-R, while it was negatively correlated with the SLR. The stem mass ratio (SMR) was negatively correlated with only the SLR. The daughter/ parent ramet mass ratio $(\mathrm{D} / \mathrm{P})$ was negatively correlated with the SLR and positively correlated with the RL, N-R, height and biomass (Figure 5). 
IJCCSM

12,5

564

Figure 5.

Correlations analysis among plant growth traits each nitrogen treatment

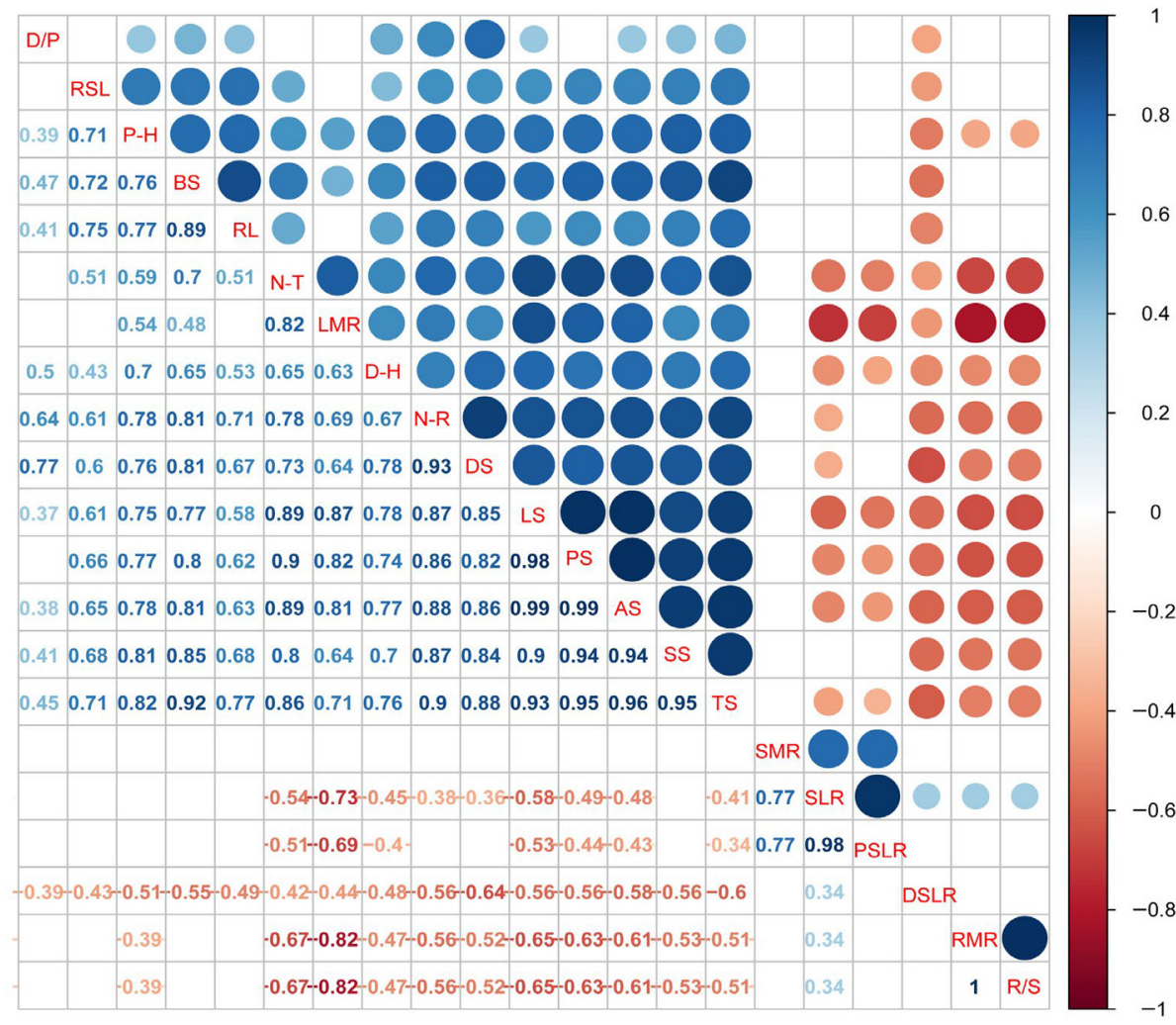

Notes: Abbreviations indicate the following: $\mathrm{N}-\mathrm{T}=$ number of tillers; $\mathrm{N}-\mathrm{R}=$ number of ramets; $\mathrm{P}-\mathrm{H}=$ parent ramet heights; $\mathrm{D}-\mathrm{H}=$ daughter ramet heights; $\mathrm{PS}=$ parent ramet mass; $\mathrm{DS}=$ daughter ramet mass; $\mathrm{AS}=$ above-ground mass; $\mathrm{SS}=$ stem mass; $\mathrm{LS}=$ leaf mass; $\mathrm{BS}=$ below-ground mass; $\mathrm{TS}=$ total biomass; $\mathrm{RL}=$ rhizome length; $\mathrm{RSL}=$ rhizome spacer length; SLR = stem/leaf ratio; PSLR = parent ramet stem/leaf ratio; DSLR = daughter ramet stem/leaf ratio; $\mathrm{D} / \mathrm{P}=$ daughter/parent ramet mass ratio; $\mathrm{SMR}=$ stem mass ratio; $\mathrm{LMR}=$ leaf mass ratio; $\mathrm{RMR}=$ root mass ratio; $\mathrm{R} / \mathrm{S}=$ root/shoot. Blue represents positive correlations and red represents negative correlations. The darker the color and the larger the circle, the stronger the correlation. Circles indicate significant correlations $(p<0.05)$ and blank spaces are not significant

\section{Discussion}

Arid and semiarid regions are among those where $\mathrm{N}$ deposition increases rapidly, which seriously affects the productivity, community structure, species diversity, nutrient cycling and other ecosystem functions of grassland ecosystems. L. chinensis is the dominant species in the arid and semiarid region on the eastern edge of the Eurasian steppe (Li et al., 2014) and $\mathrm{N}$ is one of the main limiting factors for plant growth in this region (Niu et al., 2009). Therefore, the increase in atmospheric $\mathrm{N}$ deposition driven by climate change has an important influence on the growth of L. chinensis. In the present study, we found that $\mathrm{N}$ addition could promote the clonal propagation of $L$. chinensis, but the magnitude of the 
positive effect decreased at a relatively high rate. Under favorable environmental conditions, clonal plants can achieve maximum clonal expansion by monopolizing space and resources (Prati and Schmid, 2000). Previous studies have shown that nutrient application could increase the biomass and number of ramets and the production of new rhizomes (Bai et al., 2009; Hutchings and de Kroon, 1994). Our results showed that N addition could significantly increase the ramet number, rhizome length, rhizome spacer length, biomass of mother ramets and daughter ramets and belowground $L$. chinensis population when the $\mathrm{N}$ addition was greater than $4 \mathrm{~g} \mathrm{~N} \mathrm{~m}^{-2}$, but the clonal growth ability of L. chinensis decreased;

Clonal growth of Leymus chinensis

565 and stem biomass of mother ramets significantly decreased when the $\mathrm{N}$ addition was greater than $32 \mathrm{~g} \mathrm{~N} \mathrm{~m}^{-2}$. The results indicated that an $\mathrm{N}$ addition of more than $4 \mathrm{~g} \mathrm{~N} \mathrm{~m}^{-2}$ had a significant impact on the L. chinensis population and the maximum $\mathrm{N}$ addition rate was $32 \mathrm{~g} \mathrm{~N} \mathrm{~m}^{-2}$, below which the amount favored growth and the plant growth reached the optimal level; however, at levels greater than $32 \mathrm{~g} \mathrm{~N} \mathrm{~m}^{-2}$, the positive effect decreased. Furthermore, $\mathrm{N}$ and water are the main limiting factors affecting plant growth in arid and semiarid grasslands and with the continuous increase in $\mathrm{N}$, plant species with high wateruse efficiency are dominant in the community. The addition of $\mathrm{N}$ significantly reduced the stomatal conductance of $L$. chinensis, improved its photosynthetic water-use efficiency and made it more drought resistant (Zheng and Ma, 2018). Then, this may enhance L. chinensis competitiveness in grasslands where water is a major limiting factor (Bai et al., 2008).

L. chinensis is a typical rhizome clone plant that occupies niche space, captures belowground resources and propagates growth by elongating the rhizome (Yang et al., 1995). The rhizome could grow farther from the mother ramets and produce more ramets, which could avoid competition between daughter and mother ramets to some extent, thus achieving population recruitment (Bai et al., 2009). This result also explained our result in which $\mathrm{N}$ addition simultaneously increased the tiller-based ramet number, rhizome-based ramet number and rhizome length of $L$. chinensis, which had a significant positive correlation and had consistent rules across different $\mathrm{N}$ gradients (Figures 1 and 3). In addition, with sufficient $\mathrm{N}$, the accumulation capacity of aboveground biomass and the production capacity of daughter ramets were increased because of the improvement of the photochemical capacity of the mother ramets, while the increase in $\mathrm{N}$ nutrition also led to the accumulation of more dry matter on the daughter ramets. Therefore, the biomass of both the mother ramet and the daughter ramets significantly increased (Figure 4). At the same time, the growth of belowground organs was significantly promoted, showing an increase in biomass, an increase in rhizome length and a change in rhizome spacer length. Moreover, the daughter ramet biomass was significantly positively correlated with parent ramet biomass, rhizome length and rhizome spacer length, which may be determined by the available resources for rhizome tissue storage (Granéli et al., 1992). This growth strategy indicated that the spatial distribution of daughter ramets depended on parent mass and with the increase in parent mass, the rhizome length increased, daughter ramets were produced and the spacing between them was greater (Batzer et al., 2017).

Plants obtain nutrients, water, light and other resources by adjusting the biomass allocation among organs to maximize their growth rate and thus respond to various environmental conditions (Bloom et al., 1985; Poorter and Nagel, 2000; Chapin et al., 1987). Biomass allocation is a key factor in understanding plant structure and dynamic processes in different environmental conditions (Zhang et al., 2017; Chen et al., 2020). From the perspective of biomass allocation strategies, the results showed that $\mathrm{N}$ addition increased aboveground and belowground biomass at the same time, but the increase in belowground biomass was lower than that of the aboveground biomass. Furthermore, $4 \mathrm{~g} \mathrm{~N} \mathrm{~m}^{-2}$ and $32 \mathrm{~g}$ 
IJCCSM 12,5

$\mathrm{N} \mathrm{m}^{-2}$ remained the key thresholds for biomass allocation pattern transformation. When the $\mathrm{N}$ addition rate was greater than $4 \mathrm{~g} \mathrm{~N} \mathrm{~m}^{-2}$, with the increase in the $\mathrm{N}$ gradient, the biomass allocation trend changed, the aboveground biomass allocation gradually increased and the belowground biomass gradually decreased. In the range to when the $\mathrm{N}$ addition was greater than $32 \mathrm{~g} \mathrm{~N} \mathrm{~m}^{-2}$, the biomass allocation pattern changed as follows: belowground > leaf $>$ stem to leaf $>$ belowground $>$ stem (Figure 2). Moreover, the R/S significantly decreased when the $\mathrm{N}$ addition was greater than $4 \mathrm{~g} \mathrm{~N} \mathrm{~m}^{-2}$. The $\mathrm{R} / \mathrm{S}$ ratio is an important index of biomass allocation and has important value in estimating root biomass from shoot biomass (Cairns et al., 1997; Jackson et al., 1996; Mokany et al., 2006). The trade-offs between the aboveground and belowground mass proportions of the total biomass facilitated the adaptation of $L$. chinensis to $\mathrm{N}$ addition. Thus, $\mathrm{N}$ was a powerful environmental modulator for plant biomass allocation. When the $\mathrm{N}$ concentration was the sole controlling factor, plants allocated more biomass to belowground parts to obtain more nutrients when the $\mathrm{N}$ concentration was low, while plants allocated more biomass to aboveground parts to compete for light when the $\mathrm{N}$ concentration was high. This growth strategy marked $L$. chinensis occupying a larger growth space in a short time and maximizing the utilization of effective resources.

In summary, in the present study, our experiment demonstrates that $\mathrm{N}$ addition could promote the clonal growth of the $L$. chinensis population and $\mathrm{N}$ concentrations of $4 \mathrm{~g} \mathrm{~N} \mathrm{~m}^{-2}$ and $32 \mathrm{~g} \mathrm{~N} \mathrm{~m}^{-2}$ were the key thresholds that affected clonal growth and biomass allocation when $\mathrm{N}$ was the only controlling factor. However, globally, $\mathrm{N}$ deposition is far lower than $32 \mathrm{~g} \mathrm{~N} \mathrm{~m}^{-2}$. Seen from a single factor, $\mathrm{N}$ deposition can promote the clonal growth of $L$. chinensis, which adapts to increasing $\mathrm{N}$ deposition through the biomass and resource allocation of different organs and tissues and promotes the productivity of grassland ecosystems, with L. chinensis is the dominant species. Therefore, our results provide a basis for grassland-dominant species in arid and semiarid regions to cope with global change and have a positive effect on the practice of grassland ecosystem management.

\section{References}

Bai, W.M., Sun, X.Q., Wang, Z.W. and Li, L.H. (2009), "Nitrogen addition and rhizome severing modify clonal growth and reproductive modes of Leymus Chinensis population”, Plant Ecology, Vol. 205 No.1, pp. 13-21.

Bai, Y.F., Wu, J.G., Xing, Q., Pan, Q.M., Huang, J.H., Yang, D.L. and Han, X.G. (2008), "Primary production and rain use efficiency across a precipitation gradient on the Mongolia Plateau", Ecology, Vol. 89 No. 8, pp. 2140-2153.

Barker, C.G., Power, S.A., Bell, J.N.B. and Orme, C.D.L. (2004), "Effects of habitat management on heathland response to atmospheric nitrogen deposition", Biological Conservation, Vol. 120 No. 1, pp. 579-583.

Batzer, E.E., Martina, J.P., Elgersma, K.J. and Goldberg, D.E. (2017), “Clonal plant allocation to daughter ramets is a simple function of parent size across species and nutrient levels", Plant Ecology, Vol. 218 Nos 11/12, pp. 1299-1311.

Bauer, G.A., Bazzaz, F.A., Minocha, R., Long, S., Magill, A., Aber, J. and Berntson, G.M. (2004), "Effects of chronic $\mathrm{N}$ additions on tissue chemistry, photosynthetic capacity, and carbon sequestration potential of a red pine (pinus resinosa ait.) stand in the NE United States", Forest Ecology and Management, Vol. 196 No. 1, pp. 173-186.

Bloom, A.J., Chapin, F.S. and Mooney, H.A. (1985), "Resource limitation in plants - an economic analogy”, Annual Review of Ecology and Systematics, Vol. 16 No. 1, pp. 363-392. 
Bobbink, R., Hicks, K., Galloway, J., Spranger, T., Alkemade, R., Ashmore, M., Bustamante, M., Cinderby, S., Davidson, E., Dentener, F., Emmett, B., Erisman, J.W., Fenn, M., Gilliam, F., Nordin, A., Pardo, L. and De, V.W. (2010), "Global assessment of nitrogen deposition effects on terrestrial plant diversity: a synthesis”, Ecological Applications, Vol. 20 No. 1, pp. 30-59.

Bogdziewicz, M., Crone, E.E., Steele, M.A. and Zwolak, R. (2017), "Effects of nitrogen deposition on reproduction in a masting tree: benefits of higher seed production are trumped by negative biotic interactions", Journal of Ecology, Vol. 105 No. 2, pp. 310-320.

Cairns, M.A., Brown, S., Helmer, E.H. and Baumgardner, G.A. (1997), "Root biomass allocation in the

Clonal growth of Leymus chinensis world's upland forests", Oecologia, Vol. 111 No. 1, pp. 1-11.

Chapin, F.S., Bloom, A.J., Field, C.B. and Waring, R.H. (1987), "Plant responses to multiple environmental factors", BioScience, Vol. 37 No. 1, pp. 49-57.

Chen, J.F., Ren, W.J., Chou, Q.C., Su, H.J., Ni, L.Y., Zhang, M., Liu, Z.G. and Xie, P. (2020), “Alterations in biomass allocation indicate the adaptation of submersed macrophytes to low-light stress", Ecological Indicators, Vol. 113.

Clark, C.M. and Tilman, D. (2008), "Loss of plant species after chronic low-level nitrogen deposition to prairie grasslands", Nature, Vol. 451 No. 7179, pp. 712-715.

Eckert, C.G. (2002), "The loss of sex in clonal plants”, Evolutionary Ecology, Vol. 15 Nos 4/6, pp. 501-520.

Farrer, E.C. and Suding, K.N. (2016), "Teasing apart plant community responses to N enrichment: the roles of resource limitation, competition and soil microbes”, Ecology Letters, Vol. 19 No. 10, pp. 1287-1296.

Frenne, P.D., Blondeel, H., Brunet, J., Caron, M.M., Chabrerie, O., Cougnon, M., Cousins, S.A.O., Decocq, G., Diekmann, M., Graae, B.J., Hanley, M.E., Heinken, T., Hermy, M., Kolb, A., Lenoir, J., Liira, J., Orczewska, A., Shevtsova, A., Vanneste, T. and Verheyen, K. (2018), "Atmospheric nitrogen deposition on petals enhances seed quality of the Forest herb anemone nemorosa", Plant Biology, Vol. 20 No. 3, pp. 619-626.

Galloway, J.N., Townsend, A.R., Erisman, J.W., Bekunda, M., Cai, Z., Freney, J.R., Martinelli, L.A., Seitzinger, S.P. and Sutton, M.A. (2008), "Transformation of the nitrogen cycle: recent trends, questions, and potential solutions", Science, Vol. 320 No. 5878, pp. 889-892.

Galloway, J.N., Dentener, F.J., Capone, D.G., Boyer, E.W., Howarth, R.W., Seitzinger, S.P., Asner, G.P., Cleveland, C.C., Green, P.A., Holland, E.A., Karl, D.M., Michaels, A.F., Porter, J.H., Townsend, A. R. and Vörösmarty, C.J. (2004), "Nitrogen cycles: past, present, and future", Biogeochemistry, Vol. 70 No. 2, pp. 153-226.

Garnier, E., Stahl, U., Laporte, M.-A., Kattge, J., Mougenot, I., Kuhn, I., Laporte, B., Amiaud, B., Ahrestani, F.S., Bonisch, G., Bunker, D.E., Cornelissen, J.H.C., Diaz, S., Enquist, B.J., Gachet, S., Jaureguiberry, P., Kleyer, M., Lavorel, S., Maicher, L., Perez-Harguindeguy, N., Poorter, H., Schildhauer, M., Shipley, B., Violle, C., Weiher, E., Wirth, C., Wright, I.J. and Klotz, S. (2017), "Towards a thesaurus of plant characteristics: an ecological contribution”, Journal of Ecology, Vol. 105 No. 2, pp. 298-309.

GranéLi, W., Weisner, S.E.B. and Sytsma, M.D. (1992), "Rhizome dynamics and resource storage in phragmites Australis", Wetland Ecology and Management, Vol. 1, pp. 239-247.

Hautier, Y., Niklaus, P.A. and Hector, A. (2009), "Competition for light causes plant biodiversity loss after eutrophication”, Science, Vol. 324 No. 5927, pp. 636-638.

Hooper, D.U. and Johnson, L. (1999), "Nitrogen limitation in dryland ecosystems: responses to geographical and temporal variation in precipitation", Biogeochemistry, Vol. 46 Nos 1/3, pp. 247-293.

Hutchings, M.J. and De Kroon, H. (1994), "Foraging in plants: the role of morphological plasticity in resource acquisition", Advances in Ecology Research, Vol. 25, pp. 159-238.

Isbell, F., Reich, P.B., Tilman, D., Hobbie, S.E., Polasky, S. and Binder, S. (2013), "Nutrient enrichment, biodiversity loss, and consequent declines in ecosystem productivity", Proceedings of the National Academy of Sciences, Vol. 110 No. 29, pp. 11911-11916. 
IJCCSM 12,5

\section{8}

Iversen, C.M., Mccormack, M.L., Powell, A.S., Blackwood, C.B., Freschet, G.T., Kattge, J., Roumet, C., Stover, D.B., Soudzilovskaia, N.A., Valverde-Barrantes, O.J., van Bodegom, P.M. and Cyrille Violle, C. (2017), "A global fine-root ecology database to address below-ground challenges in plant ecology”, New Phytologist, Vol. 215 No. 1, pp. 15-26.

Jackson, R.B., Canadell, J., Ehleringer, J.R., Mooney, H.A., Sala, O.E. and Schulze, E.D. (1996), “A global analysis of root distributions for terrestrial biomes", Oecologia, Vol. 108 No. 3, pp. 389-411.

Koivunen, S., Saikkonen, K., Vuorisalo, T. and Mutikainen, P. (2004), "Heavy metals modify costs of reproduction and clonalgrowth in the stoloniferous herb potentilla anserine", Evolutionary Ecology, Vol. 18 Nos 5/6, pp. 541-561.

Li, Y.Y., Lu, X.T., Wang, Z.W., Zhou, C. and Han, X.G. (2014), "Linking relative growth rates to biomass allocation: the responses of the grass Leymus Chinensis to nitrogen addition", PhytonInternational Journal of Experimental Botany, Vol. 83 No. 2, pp. 283-289.

Liu, X., Xu, W., Du, E., Pan, Y. and Goulding, K. (2016), "Reduced nitrogen dominated nitrogen deposition in the United States, but its contribution to nitrogen deposition in China decreased", Proceedings of the National Academy of Sciences, Vol. 113 No. 26, pp. E3590-E3591.

Michopoulos, P., Baloutsos, G., Economou, A. and Nikolis, N. (2004), "Effects of nitrogen deposition on nitrogen cycling in an Aleppo pine stand in Athens, Greece", Science of the Total Environment, Vol. 323 Nos 1/3, pp. 211-218.

Mokany, K., Raison, R.J. and Prokushkin, A. (2006), "Critical analysis of root: shoot ratios in terrestrial biomes", Global Change Biology, Vol. 12 No. 1, pp. 84-96.

Niu, S., Yang, H., Zhang, Z., Wu, M., Lu, Q., Li, L., Han, X. and Wan, S. (2009), "Non-additive effects of water and nitrogen addition on ecosystem carbon exchange in a temperate steppe", Ecosystems, Vol. 12 No. 6, pp. 915-926.

Philbrick, C.T. and Les, D.H. (1996), "Evolution of aquatic angiosperm reproductive systems", BioScience, Vol. 46 No. 11, pp. 813-826.

Poorter, H. and Nagel, O. (2000), "The role of biomass allocation in the growth response of plants to different levels of light, $\mathrm{CO}_{2}$, nutrients and water: a quantitative review", Functional Plant Biology, Vol. 27 No. 6, pp. 595-607.

Prati, D. and Schmid, B. (2000), "Genetic differentiation of life-history traits within populations of the clonal plant ranunculus reptans”, Oikos, Vol. 90 No. 3, pp. 442-456.

Simkin, S.M., Allen, E.B., Bowman, W.D., Clark, C.M., Belnap, J., Brooks, M.L., Cade, B.S., Collins, S.L., Geiser, L.H., Gilliam, F.S., Jovan, S.E., Pardo, L.H., Schulz, B.K., Stevens, C.J., Suding, K.N., Throop, H.L. and Waller, D.M. (2016), "Conditional vulnerability of plant diversity to atmospheric nitrogen deposition across the USA", Proceedings of the National Academy of Sciences, Vol. 113 No. 15, pp. 4086-4091.

Tian, Q.Y., Liu, N.N., Bai, W.M., Li, L.H. and Zhang, W.H. (2015), "Disruption of metal ion homeostasis in soils is associated with nitrogen deposition-induced species loss in an Inner Mongolia steppe", Biogeosciences, Vol. 12 No. 11, pp. 3499-3512.

Tian, Q.Y., Liu, N.N., Bai, W.M., Li, L.H., Chen, J.Q., Reich, P.B., Yu, Q., Guo, D.L., Smith, M.D., Knapp, A.K., Cheng, W.X., Lu, P., Gao, Y., Yang, A., Wang, T.Z., Li, X., Wang, Z.W., Ma, Y.B., Han, X.G. and Zhang, W.H. (2016), "A novel soil manganese mechanism drives plant species loss with increased nitrogen deposition in a temperate steppe”, Ecology, Vol. 97 No. 1, pp. 65-74.

Valverde-Barrantes, O.J., Freschet, G.T., Roumet, C. and Blackwood, C.B. (2017), "A worldview of root traits: the influence of ancestry, growth form, climate and mycorrhizal association on the functional trait variation of fine-root tissues in seed plants", New Phytologist, Vol. 215 No. 4, pp. 1562-1573.

Vet, R., Artz, R.S., Carou, S., Shaw, M., Ro, C.U., Aas, W., Baker, A., Bowersox, V.C., Dentener, F., GalyLacaux, C., Hou, A., Pienaar, J.J., Gillett, R., Forti, M.C., Gromov, S., Hara, H., Khodzher, T., Mahowald, N.M., Nickovic, S., Rao, P.S.P. and Reid, N.W. (2014), "Chemistry and deposition of 
sulfur, nitrogen, sea salt, base cations, organic acids, acidity and $\mathrm{pH}$, and phosphorus", Atmospheric Environment, Vol. 93 No. S1, pp. 3-100.

Vitousek, P.M., Mooney, H.A., Lubchenco, J. and Melillo, J.M. (1997), "Human domination of earth's ecosystems", Science, Vol. 277 No. 5325, pp. 494-499.

Walker, A.P., McCormack, M.L., Messier, J., Myers-Smith, I.H. and Wullschleger, S.D. (2018), "Traits covariance: the functional warp of plant diversity?”, New Phytologist, Vol. 216 No. 4, pp. 976-980.

Yang, Y.F., Liu, G.C. and Zhang, B.T. (1995), "An analysis of age structure and the strategy for asexual propagation of aneurolepidium Chinense population”, Acta Botanical Sinica, Vol. 37 No. 2, pp. 147-153.

Zhang, K., Su, Y.Z. and Yang, R. (2017), "Biomass and nutrient allocation strategies in a desert ecosystem in the Hexi corridor, northwest China", Journal of Plant Research, Vol. 130 No. 4, pp. 699-708.

Zheng, M.H., Huang, J., Chen, H., Wang, H. and Mo, J.M. (2015), “Responses of soil acid phosphatase and beta-glucosidase to nitrogen and phosphorus addition in two subtropical forests in Southern China", European Journal of Soil Biology, Vol. 68, pp. 77-84.

Zheng, Z. and Ma, P.F. (2018), "Changes in above and belowground traits of a rhizome clonal plant explain its predominance under nitrogen addition”, Plant and Soil, Vol. 432 Nos 1/2, pp. 415-424.

\section{Further reading}

Zhang, G.G., Kang, Y.M., Han, G.D. and Sakurai, K. (2011), "Effect of climate change over the past half century on the distribution, extent and NPP of ecosystems of Inner Mongolia", Global Change Biology, Vol. 17 No. 1, pp. 377-389.

\section{Corresponding author}

Ding Huang can be contacted at: huangding@263.net

For instructions on how to order reprints of this article, please visit our website: 